\title{
Jurisprudential Analysis of the Execution of the Inheritance of Adopted Children
}

\author{
Ahmad Akhsin 1
}

\begin{abstract}
The issues raised in This research is: What is the legal basis for the consideration of the Judge and the ijtihad style of the Religious Court Judges at the Batang Religious Court in settling the inheritance of adopted children? What factors influence the style of the decision of the Batang Religious Court Judge in the settlement of the case of adoptive son inheritance? The method used in this research is a normative juridical approach and the research specification uses descriptive analytical.

The main tasks of the judiciary in Indonesia in receiving, examining, adjudicating and resolving any problems raised are carried out by judges. Judges here, apart from functioning as law enforcers, are also required to enforce law and justice. Here the judge will be required to do not just as a mouthpiece or mouthpiece Law, but more than that it is required to explore the law in every decision for the sake of upholding justice. In matters where there is no sharih text, the judge's ijtihad style is characterized by the use of unwritten sources of law, including istishhab and maslahah mursalah. Although it was not explicitly stated in the consideration of the decision, contextually ishtishhab was used as an unwritten source in the settlement of the case of the inheritance of adopted children. The Panel of Judges at the Batang Religious Court in the settlement of the case of the inheritance of adopted children who get inheritance rights through the mandatory will use ijtihad integrative between ijtihad intiqa'i and ijtihad insya'i according to the concept of Yusuf Al Qardawi, Meanwhile, the factors that influence the style of the judge's decision at the Batang Religious Court consist of two factors, internal and external factors of the judge, each of which has a dominant influence.
\end{abstract}

Key Words: Jurisprudence; ijtihad; inheritance; adopted children; mandatory will

\section{Introduction}

According to Bustanul Arifin, since the enactment and promulgation of Law no. 7 of 1989 concerning the Religious Court on 29 December 1989,2then in a judicial-institutional-legal manner, the Religious Courts are established in Indonesia, so that the Religious Courts have the same position as courts, standing equally high. equivalent to other state courts. Therefore, in order to optimize the religious justice system, especially in the field of material law, the government legalized the draft Islamic Law Compilation in the form of Presidential Instruction

\footnotetext{
${ }^{1}$ Religious Court Judge

${ }^{2}$ Law No.7 of 1989 was passed through the State Gazette of the Republic of Indonesia Year 1989 Number 49. Ahmad Rofiq, 2001, Pembaharuan Hukum Islam di Indonesia, Cet.I, Yogyakarta: Gama Media, p. 83.
} 
No.1 of 1991 dated 10 June 1991, ${ }^{3}$ who ordered the Minister of Religion to disseminate the Compilation of Islamic Law for use by government agencies and communities that need it. The instruction was implemented by Decree of the Minister of Religion No.154 dated 22 July 1991.4

Judges of the Religious Courts until the enactment of the Compilation of Islamic Law in 1991 in formulating cases were always guided by the classic yellow books which were very diverse, as a consequence the decisions between one judge and another, whether in a Religious Court or not, were not necessarily the same. Reality like this, according to JND. Anderson can be categorized as an unsatisfactory justice system. ${ }^{5}$ Therefore, with the enactment of the Compilation of Islamic Law. In 1991, Religious Court Judges were able to use guidelines in deciding cases although it did not rule out the possibility that judges would still refer to the classic yellow books if deemed necessary.

Cases accepted by the Religious Courts as one of the State Judiciary Bodies are religious civil cases as regulated in Article 49 of Law Number 3 of 2006, namely disputes on marriage, inheritance, wills, grants, waqf, zakat, infaq, shadaqoh and sharia economics.

In the Civil Procedure Law there is a principle that Judges are passive, meaning that the broad scope of the case is very much determined by the parties in the case, Judges are not allowed to order, add claims and may not decide what is not being challenged, there is also another principle, namely Judges are waiting, meaning that the presence or absence of a case is highly submitted to the parties (justiciabelen)

A court in this case is like a hospital awaiting the arrival of a patient, even so if a case is filed there is no reason for the Judge not to resolve it. The case must be decided and the judgment implemented.

If the law is clear the Judge will apply the law (rechtstoepassing), if the law is not clear the Judge will interpret it and if the law does not exist, the Judge will dig up the law (rechtsvinding) or carry out ijtihad to the fullest of his ability.

The Religious Court is one of the judicial institutions in Indonesia which has the authority to accept, examine, try and resolve special civil cases of first degree between Muslims in the field of marriage, inheritance, wills, sadaqah and grants made based on Islamic law, waqf, zakat, infaq and shodaqoh as well as shari'ah economics. ${ }^{6}$ In the field of inheritance, the Religious Court has the authority to determine who is the heir, determine the inheritance property, the share of each heir and carry out the distribution of the inheritance. ${ }^{7}$

\footnotetext{
3This draft compilation of Islamic law is the result of a workshop held in Jakarta on February 25, 1988. See Cik Hasan Basri, 1999, Kompilasi Hukum Islam dalam Sistem Hukum Nasional, cet.1(Jakarta: Logos Wacana Ilmu, p.1. While the history of the compilation of Islamic Laws, see Ditbinbapera, Directorate General of Islamic Bodybuilding, Ministry of Religion RI, Kompilasi Hukum Islam.

4 Decided that all agencies of the Ministry of Religion and related government agencies to disseminate KHI in the field of Marriage Law, Inheritance and Waqf to be used in solving problems in this field.

${ }_{5}^{5}$ JD Anderson, Islamic Law in The Modem World. New York University Press. 1975. p. 85.

${ }^{6}$ See Article 49 paragraph l of Law Number 7 of 1989 concerning Religious Courts.

${ }^{7}$ Regarding this, see Article 49 paragraph 3 of Law Number 7 of 1989.
} 
In the case of inheritance in general, if someone dies, then the heirs are husband or wife and their children. In other cases it is possible for a husband or wife and their children to inherit together with other members, namely the mother and father. In fact, it can also happen that those who become heirs are their siblings because there are no children and descendants of muwarris.

With regard to inheritance, generally when an heir dies, he leaves several heirs who are then the inheritor's inheritance after deducting the maintenance costs required by the deceased heir, as well as debts, wills or gifts made while still alive can be directly distributed to the heirs, this is the same as the opinion, that it is better if the inheritance can be divided as soon as possible when everything is done for an heir who dies.

There are several conditions in the distribution of inheritance, namely that first, the death of the heir (muwarrits) both haqiqy, hukmy and also died taqdiry, secondly, the life of the heirs (warits) at the time of the death of muwarrits and third, there were no obstructions to destroy (mawani'ul irtsi), whether due to slavery, murder, different religion or because of different countries. ${ }^{8}$

Then if there are heirs (heirs) there are adopted children, then problems will also arise. Whereas in addition to an adopted child inheriting from his adoptive father, he still receives an inheritance from his own biological father, the twin inheritance rights for adopted children are likened to Joyo Tirto as a person who can receive "water from two sources of water".

That the word Ijtihad comes from the root word Jahada means to really devote all one's abilities or bear burdens. ${ }^{9}$ In language it can be interpreted as the maximum effort made by someone in order to achieve goals, while in terms of terms it is defined as the maximum thought effort made by certain people or experts in an effort to find the truth from its source in various fields of Islamic science. ${ }^{10}$

Wahbah al-Zuhaili argues that Ijtihad is to exert all the mental energy of a fiqh expert in order to produce syara 'law which is dhanni. ${ }^{11}$ Similar understanding was given by Muhammad Khudlari Beik and other scholars, al-Ghazali and alAmudi. ${ }^{12}$

Abu Zahrah further broadened his understanding that Ijtihad was an effort to think optimally by its experts in order to extract law from its source (Al-Qur'an and Sunnah) and apply it. ${ }^{13}$

From the definition of Abu Zahrah, two meanings can be contained: first, efforts to think optimally by an expert in order to explore and obtain law from the sources of the Qur'an and Sunnah and second, efforts made by someone in order to

\footnotetext{
${ }^{8}$ Fatchur Rahman, 1981, Ilmu Waris. Cet. 2 (Bandung : PT. Al Ma'arif, p. 79

${ }^{9}$ Wahbah al-Zuhaili, al-Wasith fi Ushul al Fiqh al-Islami, cet. III, Dar Al Kitab 1977/1978, p. 480

${ }^{10}$ Satria Effendi M. Zein, "Ijtihad dan Hakim Pengadilan Agama”, in Mimbar Hukum nomor 10 thn. IV, 1993, p. 42.

11 Wahbah al-Zuhaili, op.cit, pp. 480-481.

${ }^{12}$ Muhammad Khulari Beik, Ushul al-Fiqh, cet. III, Cairo; al-Istiqomah, tt, p. 357; Al-Ghazali, alMustashfa Min Ilm al_Ushul, Juz. II, cet. I, Mushthafa Muhammad, 1356 H, p. 101; Al-Amudi, alIhkam fi Ushul al-Ahkam, Juz III, Shabih, 1347 H, p. 139.

13 Muhammad Abu Zahrah, Ushul al-Fiqh, Daar al-Fikr al-'Arabi, tt, p. 379.
} 
apply the law. on existing problems. These two kinds of ijtihad by Muhibbin Noor are referred to as ijtihad pengandaian and ijtihad tathbiqi.

In relation to the Religious Courts, it can be interpreted as the maximum effort of the judge to explore, apply and interpret the law from the sources of the Qur'an and Sunnah and other laws and regulations, as previously carried out by good judges appointed by Rosulullah SAW, and Khulafaur Rasyidin who require very strict requirements.

Whereas the condition of Religious Court Judges in Indonesia prior to the existence of the Compilation of Islamic Law in deciding cases using jurisprudence and legal products which are scattered in classical fiqh books which are sometimes no longer relevant to current conditions so that the ijtihad required by religious court judges is not all types and forms of iitihad, but it is sufficient with the form of ijtihad tathbiqi in the opinion of Abu Zahrah.

Based on the description above, the writer is interested in discussing Ijtihad, judges at the Batang Religious Court in resolving the case of the inheritance of adopted children.

\section{Research Methods}

The approach method used in this research is the normative juridical approach. This research is descriptive analytic because it aims to provide a description of a society or a particular group of people or a description of a symptom or a relationship between two or more symptoms. In descriptive research like this, the writer will use a survey method. ${ }^{14}$ What is needed to explain the postulates studied in full in accordance with the findings in the field.In this study the data obtained are: Secondary data in the form of primary legal materials, and secondary legal materials obtained by the literature study method. The interview method is used to strengthen the results of literature studies.To analyze the collected data, qualitative analysis techniques are used which are presented in descriptive form to the data obtained.

\section{Research Results And Discussion}

Before discussing the core issue, namely the Jurisprudence analysis of the execution of the inheritance of adopted children at the Batang Religious Court in the perspective of Islamic Law, it is necessary for the author to pay attention to the concept of ijtihad by the Religious Court judges as described in the previous chapter and the legal basis used in resolving the case of the inheritance of adopted children. This is intended to further strengthen the basis or basis for judges' consideration in deciding cases of the inheritance of adopted children, either as heirs or as heirs, so that they can be accounted for more legally..

Cases which are the object of this author's research are very rare and are brought to the Religious Courts despite the fact that many such cases occur in the community.

\footnotetext{
14 Altherton \& Klenmack in Irawan Soehartono, 1999, Metode Penelitian Sosial Suatu tehnik Penelitian Bidang Kesejahteraan Sosial Lainnya, Remaja Rosda Karya, Bandung, p. 63
} 
In the Batang Religious Court itself there is only one case, namely the case of inheritance lawsuit Register Number 1049 / Pdt.G / 2002 / PA.Btg. the case was submitted to the Batang Religious Court on September 11, 2002 then decided by the panel of judges on February 24, 2003 and the decision was implemented or executed on June 11, 2003.15

\subsection{The legal basis for the judge's consideration and the ijtihad style of the Batang Religious Court judges in settling the inheritance of adopted children.}

The legal basis for the judge's consideration in resolving inheritance disputes for adopted children is based on the Al-Qur'an and Sunnah and then also uses statutory regulations which, although not written, contain regulations such as those listed below:

1). 1945 Constitution.

2). HIR - Staatsblad Number. 44 in 1941.

3). Law Number. 14 of 1970 concerning the Principles of Judicial Power jo. Law Number 35 of 1999 jo. Law Number 4 of 2004 jo. Law Number 48 of 2009.

4). Law No. 14 of 1985 regarding the Supreme Court jo. Law Number 5 of 2004 jo. Law Number 3 of 2009.

5). Law Number 7 of 1989 regarding Religious Courts jo. Law Number 3 of 2006 jo. Law Number 50 of 2009.

6). Compilation of Islamic Law.

7). Fiqh Books or Yellow Books.

8). Unwritten Legal Sources.

9). Supreme Court Jurisprudence and Judicial Bodies.

Meanwhile, the ijtihad style of the Batang Religious Court Judges in the settlement of the case emphasized more on the use of unwritten legal sources, such as the legal sources used by salaf ulama in performing ijtihad. Among the sources of the unwritten law are Istishhab and maslahah mursalah. Although it is not explicitly mentioned in the verdict, it is implicitly that the Istishhab's role is very important in resolving the adoptive anal inheritance which is the case in the case analyzed in this thesis.

From this it can be seen that the judges of the Batang Religious Court in determining the distribution of inheritance for adopted children use Istishhab as the legal basis for the settlement, namely using ijtihad a combination of ijtihad intiqa'i and ijtihad insya'i according to Yusuf al Qardawi's opinion, meaning on the one hand using ijtihad intiqa'i because choosing the opinion of existing scholars, on the other hand, also performs ijtihad itself in deciding the right of the adopted child through the mandatory will or using the ijtihad istishlahi method like the opinion of Muhammad Musthafa Syalabi.

It should also be concluded that the Panel of Judges in its ijtihad used Satjipto Rahardjo's progressive theory, although not openly, because the panel

${ }^{15}$ Interview with Shobirin 
with a clear conscience had placed the adopted son of the heir, considered the same as his own biological child who received or obtained the right to share the inheritance even though through compulsory will. This is evident because the parties, including the child, have felt that they have received true justice in this case, it is evident that the parties have not filed for legal remedies, both verzet legal remedies on the verstek decision and legal reconsideration efforts.

\section{B. Factors Affecting the Pattern of Judges at the Batang Religious Court in the settlement of the inheritance of adopted children.}

In the General Explanation number 1, third paragraph of Law Number 50 of 2009 concerning the second amendment to Law Number 7 of 1989 it is emphasized that the highest supervision regarding both judicial and non-judicial technicalities, namely organizational, administrative and financial matters is under the authority of the Supreme Court. Meanwhile, to maintain and uphold the honor, dignity and behavior of judges, external supervision is carried out by the Judicial Commission

The second amendment to the Law is also intended to strengthen the basic principles in the administration of judicial power, namely so that the principles of judicial independence and the principles of judge freedom can run parallel with the principles of integrity and accountability of judges.

Judges must have the knowledge and art of leading trials, namely the art and skills to explore, contact, convince and invite parties so that through the applicable procedural law they are willing and able: first, settle cases in simple, fast and low cost, relaxed ways and human. In Article 4 of Law Number 48 of 2009 it is stated that (1) the Court judges according to the law and does not discriminate between people, (2) The Court assists justice seekers and tries to overcome all obstacles and obstacles to achieve a simple, fast and costly trial. light. The previous article, namely Article 2 paragraph (4) stated that the trial was carried out simply, quickly and at low cost. Second, produce a fair verdict, true and satisfying and can be accounted for before God Almighty; Third, maintaining harmony, togetherness and peace between the parties concerned, as long as the settlement of the case takes place until after the decision is passed. ${ }^{16}$

The judge must be active in presiding over the trial and make serious efforts to achieve peace between the parties, or if the case is to be decided by the judge it should be pursued by the methods mentioned above. Judges must master the knowledge of law as a provision for case settlement, which is equipped with management science and humanities as their supporting tools which are applied in an integrated manner. The judge must be a superior person who is able to actualize himself and become a fully human being, but must not feel super. ${ }^{17}$

In order to realize a fair, correct, satisfying and accountable decision before God Almighty, there are certain factors that differentiate the results of a judge's verdict from another.

\footnotetext{
${ }^{16}$ A. Mukti Arto, 2001, Mencari Keadilan: Kritik dan Solusi Terhadap Praktik Peradilan Perdata di Indonesia, Prints I, Yogyakarta: Pustaka Pelajar, p. 143-144.

${ }^{17}$ Ibid.
} 
In a broader context, Mukti Arto mentions 12 factors that affect case settlement and control of these factors so as to facilitate the process of resolving cases with complete, final and satisfying results. (1) The substance of the case; (2) Seekers of justice; (3). Attorney; (4). Legal substance; (5). Readiness of evidence; (6). Facilities and infrastructure; (7). Legal Culture; (8). Communication at trial; (9). Influence from outside; (10). Court Apparatus; (11). Judge; and (12). Management factor. 18

One of the most dominant factors is the identification of fiqh with Islamic law which gives birth to decisions in accordance with the school of fiqh adhered to by each judge. According to Yahya Harahap, the identification of fiqh with Islamic law has given birth to a very wrong application. In fact, according to Yahya, it is very wrong to identify Islamic law with fiqh. Fiqh is not a positive law that has been formulated systematically and uniquely. Fiqh is the content of the teachings or science of Islamic law. That is why fiqh is called the doctrine of Islamic law. Or it is more accurate to say that fiqh is the opinion and teachings of the imams of the schools of thought. The books of fiqh are not books of law, but books that contain the opinions and ijtihad of the mazhab imams. ${ }^{19}$

As a result of the attitudes and behavior of the judges who identified fiqh with shari'ah or Islamic law, various decisions of the Religious Courts were born, according to the mazhab background adopted by each judge. The decisions of the Religious Courts have very disparities between the decisions of one another in cases of the same cases. The Religious Courts in resolving cases occurred battles between schools. The law is left behind. The verdict is not based on law but based on the doctrine of the school which has been described in the books of fiqh. In the event of implementing and enforcing law that competes with the fiqh of the mazhab, the values of truth and justice are embodied in the rulings of the Religious Courts, not based on law or shari'ah, but solely on the teachings of fiqh. ${ }^{20}$

Meanwhile, Ahmad Rofiq saw the identification of fiqh with syari'at. According to him, the identification of fiqh with shari'a is an internal factor that hinders the process of changing or renewing the law itself. In fact, according to him, the perception of some people who identify fiqh which nota bene is the intellectual work of a faqîh / ulama, and its relative truth, and influenced by the socio-cultural formulation, with shari'at which is a product of God and is absolute in nature, often results in a solution. laws that are not only actual but tend to deny the legal values and norms that live in society. Therefore, he continued, Islamic law does not only cover fiqh, but some are in the form of fatwas, court decisions, ${ }^{21}$

After the author conducted interviews with several judges at the Batang Religious Court, ${ }^{22}$ The factors that influence the style of the judge's decision at the Batang Religious Court, in the case of the inheritance of the adopted child, are

\footnotetext{
${ }^{18}$ Interview with Mukti Arto in Jakarta.

${ }^{19}$ See, M. Yahya Harahap, 1999, Informasi Materi Kompilasi Hukum Islam: Mempositifkan Abstraksi Hukum Islam", in Cik Hasan Bisri (ed.), KHI dan Peradilan Agama dalam Sistem Hukum Nasional, Jakarta: Logos wacana Ilmu, p. $21-22$.

${ }^{20}$ Ibid, p. 22-23.

${ }^{21}$ Ahmad Rofiq, 2001, Pembaharuan Hukum Islam di Indonesia, Print I, Yogyakarta: Gama Media, p. 101.

${ }^{22}$ Interview with Masuri Anwar, Shobirin who is a member of the Panel of Judges for the aquo case.
} 
divided into two factors, namely the judge's internal factor and the judge's external factor.

Some of these factors are factors that support the improvement of legal services and justice in the settlement of inheritance cases and some are inhibiting factors, for example there are no specific rules regarding civil procedure law for inheritance cases in a separate law.

Internal factors for judges include: first, the judge's educational background. Of the thirteen judges at the Batang Religious Court, all of them are shari'ah scholars, and most also have law degrees, and some have even completed their Masters (S2) program, some are Masters in Law and some are Masters in Sharia Economics, meanwhile some are currently pursuing postgraduate studies (S2). Seeing the educational background of the judges at the Batang Religious Court, it has a very big influence on the settlement of existing cases, because they are able to understand the regulations related to the duties of the Religious Courts in general, as well as being able to understand the legal basics of the yellow books in decide the case. ${ }^{23}$ Although the judges' inaccuracy is still visible in drafting verdicts, for example: the first dictum is incomplete. Second, the tendency to choose Istishhab as an unwritten legal basis for events that are not mentioned in the essence of the texts. ${ }^{24}$ Third, the tendency of the judges to use the integrative ijtihad model, according to the concept of Yusuf al-Qardawi. In determining the status of adopted children, the judges in addition to looking at the opinions of previous scholars, they also tried to do ijtihad by themselves.

Fourth, high work motivation from the judges. According to Siti Damroh (Deputy Clerk of the Batang Religious Court), this high work motivation is due to the good and compact cooperation of judges, clerks and staff of the Batang Religious Court, which is very beneficial in carrying out tasks and solving existing cases. High work motivation is also based on a). the belief that work is a form of worship; b). there is adequate welfare; c). have aligned the Religious Courts with other courts; d). a comfortable and full of family atmosphere; e.). support from each work unit leader to employees.

External factors for judges, including: first, the spirit of legislation on judiciary, one of which is a simple, fast and low cost process of solving cases. According to Law Number 48 of 2009, the function of the judiciary is to implement and enforce law and justice based on Pancasila, in addition, justice must be carried out simply, quickly and at low cost. ${ }^{25}$ Second, there is a set of rules governing the working procedures of the Religious Courts. which since the promulgation of Law Number 7 of 1989 has turned into an independent judicial body. ${ }^{26}$, on an equal footing with General Courts and State Administration bodies that have the same procedural law, have an orderly administration and a unified legal frame work and unified legal opinion (unity of legal basis and uniformity of legal views), the implementation of the duties of Religious Court Judges is a unified system, which

\footnotetext{
23 Interview with Siti Damroh (Deputy Clerk of the Batang Religious Court).

24 Judging from the Decision of the Batang Religious Court Number: 1049 / Pdt.G / 2002 / PA.Btg and the results of an interview with Shobirin., A former Judge at the Batang Religious Court.

${ }^{25}$ Interview with Masykuri Anwar, a member of the aquo case board.

26 The results of an interview with Shobirin, a member of the aquo case board
} 
is executed by the judge and assisted by the clerk, secretariat and bailiff. Article 102 of Law Number 7 of 1989 concerning the Religious Courts confirms that the duties and responsibilities as well as the work procedures for court clerkship are further regulated by the Supreme Court. Then, The Supreme Court issued a decision letter Number KMA / 001 / SK / 1/1991 dated January 12, 1991 concerning the pattern of fostering and controlling the administrative administration of the Religious Courts and the High Religious Courts which were also followed by instructions on the implementation of case administration within the Religious Courts. Meanwhile, for the guidance and control of the bailiff's work procedure, a Decree of the Chief Justice of the Supreme Court was issued Number KMA / 055 / SK / X / 1996.

Third, there is no special procedural law regarding inheritance cases that regulates civil procedural law for inheritance cases. In the settlement of inheritance cases, the panel of judges at the Batang Religious Court used the civil procedural law as it applies to the general court. Meanwhile, in the Compilation of Islamic Law and Law Number 7 of 1989 only includes issues of inheritance, heirs and share rights of each heir and the implementation of the distribution. ${ }^{27}$

\section{Closing}

\subsection{Conclusion.}

Based on the description above, the conclusions that the authors get and according to the authors can answer the problems as formulated in the problem formulation, as follows: The legal basis used by the Batang Religious Court Judges in the settlement of the inheritance of adopted children at the Batang Religious Court is in principle the same as those of the Religious Court judges in Indonesia in general, namely: positive law applicable in Indonesia.Meanwhile, the ijtihad style of the Batang Religious Court Judges in the settlement of the case emphasized more on the use of unwritten legal sources, such as the legal sources used by salaf ulama in performing ijtihad. Among the sources of the unwritten law is the Istishhab. Although it is not explicitly stated in the verdict, it is implicitly that the role of Istishhab is very important in resolving the adoptive anal inheritance which is the case in the cases analyzed in this thesis.

\subsection{Suggestions}

First, It is necessary to immediately formulate a Law on Inheritance for the Religious Courts (RUUHM.PABK) on Islamic inheritance which regulates the procedures and procedural law for inheritance cases which so far still use civil procedural law in general courts.

Second, hopes that the judges who resolve the case of the inheritance of adopted children will be more careful and detailed in preparing legal considerations in their case decisions. For example, the ruling number (1) which states that the Defendants who have been summoned properly are not present are

${ }^{27}$ Interview with Maskuri Anwar, a former judge at the Batang Religious Court. 
actually still incomplete. In full, the warning should state "stating that the Defendants who had been summoned properly to appear before the trial were not present".

Here the judges can apply Satjipto Rahardjo's progressive law in practice which must prioritize conscience and legal justice, not just legal truth.

Third, the Religious Court Judges, especially the Batang Religious Court Judges, have the courage to make a breakthrough to not give a maximum portion of the adopted child, which is one-third, preferably less than one-third, as the permanent jurisprudence of the Supreme Court.

Fourth, there needs to be sufficient socialization for the parties in litigation (justiciabelen) in the Religious Courts, especially in the area of the Batang Religious Courts and the surrounding community in general, so that they understand the procedural procedures, especially the case of the inheritance of adopted children.

\section{Bibliography}

[1] Mukti Arto, 2001, Mencari Keadilan: Kritik dan Solusi Terhadap Praktik Peradilan Perdata di Indonesia, Cetakan I, Yogyakarta: Pustaka Pelajar

[2] Ahmad Rofiq, 2001, Pembaharuan Hukum Islam di Indonesia, Cet.I, Yogyakarta: Gama Media

[3] Al-Amudi, $1347 \mathrm{H}$, al-Ihkam fi Ushul al-Ahkam, Juz III, Shabih,

[4] Altherton \& Klenmack dalam Irawan Soehartono, 1999, Metode Penelitian Sosial Suatu tehnik Penelitian Bidang Kesejahteraan Sosial Lainnya, Remaja Rosda Karya, Bandung

[5] Cik Hasan Basri, 1999, Kompilasi Hukum Islam dalam Sistem Hukum Nasional, cet.1, Jakarta: Logos Wacana Ilmu.

[6] Cik Hasan Bisri (Penyunting), 1999, KHI dan Peradilan Agama dalam Sistem Hukum Nasional, Jakarta: Logos wacana Ilmu

[7] Fatchur Rahman, 1977/1978, 1981, Ilmu Waris. Cet. 2 Bandung : PT. Al Ma'arif

[8] JND Anderson, 1975, Islamic Law in The Modem World. New York University Press

[9] Muhammad Abu Zahrah, Ushul al-Fiqh, Daar al-Fikr al-'Arabi

[10] Muhammad Khulari Beik, 1356 H, Ushul al-Fiqh, cet. III, Kairo; al-Istiqomah, t.t, h.357; Al-Ghazali, al-Mustashfa Min Ilm al_Ushul, Juz. II, cet. I, Mushthafa Muhammad,

[11] Satria Effendi M. Zein, 1993, Ijtihad dan Hakim Pengadilan Agama, dalam Mimbar Hukum nomor 10 thn. IV

[12] UU No.7 Tahun 1989 tersebut disahkan melalui Lembaran Negara Republik Indonesia Tahun 1989 Nomor 49.

[13] Wahbah al-Zuhaili, al-Wasith fi Ushul al Fiqh al-Islami, cet. III, Dar Al Kitab 